Article

\title{
Synergetic effect between non-thermal plasma and photocatalytic oxidation on the degradation of gas-phase toluene: Role of ozone
}

\author{
Haoling Ye a,b, Yiqiu Liu a,b, Si Chen a,b, Haiqiang Wang a,b,*, Zhen Liu c, Zhongbiao Wu a,b \\ a Key Laboratory of Environment Remediation and Ecological Health of Ministry of Education, College of Environmental \& Resources Sciences, Zhejiang \\ University, Hangzhou 310058, Zhejiang, China \\ b Zhejiang Provincial Engineering Research Center of Industrial Boiler \& Furnace Flue Gas Pollution Control, Hangzhou 310027, Zhejiang, China \\ c Key Laboratory of Biomass Chemical Engineering of Ministry of Education, College of Chemical and Biological Engineering, Zhejiang University, \\ Hangzhou 310007, Zhejiang, China
}

\section{A R T I C L E I N F}

\section{Article history:}

Received 29 August 2018

Accepted 8 October 2018

Published 5 May 2019

\section{Keywords:}

Non-thermal plasma

Photocatalytic oxidation

Synergetic effect

Ozone

Toluene

\begin{abstract}
A B S T R A C T
In this study, a hybrid process using non-thermal plasma (NTP) and photocatalytic oxidation (PCO) was adopted for the degradation of gas-phase toluene using $\mathrm{TiO}_{2}$ as the photocatalyst. To discover the synergetic effect between NTP and PCO, the performances of both sole $\left(\mathrm{O}_{3}, \mathrm{UV}\right.$, NTP, and PCO) and combined $\mathrm{CO}_{3}+\mathrm{TiO}_{2}, \mathrm{O}_{3}+\mathrm{UV}, \mathrm{NTP}+\mathrm{UV}, \mathrm{O}_{3}+\mathrm{PCO}$, and $\left.\mathrm{NTP}+\mathrm{PCO}\right)$ processes were investigated from different perspectives, such as the toluene removal efficiency, selectivity of $\mathrm{CO}_{x}$, mineralization rate, ozone utilization, and the generation of by-products. The toluene removal efficiency of the combined NTP + PCO process was $80.2 \%$, which was much higher than that of a sole degradation process such as NTP (18.8\%) and PCO (13.4\%). The selectivity of $\mathrm{CO}_{2}$ and the ozone utilization efficiency also significantly improved. The amount of by-products in the gas phase and the carbon-based intermediates adsorbed on the catalyst surface dramatically reduced. The improvement in the overall performances of the combined NTP + PCO process was mainly ascribed to the efficient utilization of ozone in the photocatalytic oxidation, and the ozone further acting as an electron acceptor and scavenger, generating more hydroxyl radicals and reducing the recombination of electron-hole pairs.
\end{abstract}

(C) 2019, Dalian Institute of Chemical Physics, Chinese Academy of Sciences. Published by Elsevier B.V. All rights reserved.

\section{Introduction}

Emissions of volatile organic compounds (VOCs) are an important cause of air pollution, not only harming the human health and the ecological environment directly, but also leading to the formation of PM2.5, ozone, and photochemical smog [1-4]. Advanced oxidation processes such as thermal catalytic oxidation [5-7], non-thermal plasma (NTP) [8-13], and photocatalytic oxidation (PCO) [14-18] have been deemed efficient technologies for air purification. Although NTP technology exhibits high efficiency with regard to the removal of VOCs with a short residence time and relatively low energy consumption, it also suffers from the disadvantages of low selectivity in the mineralization of VOCs and the generation of undesirable by-products such as ozone $[8,14]$. When applied to the PCO process, it possesses high activity toward various contaminants and benign final products $\left(\mathrm{CO}_{2}, \mathrm{H}_{2} \mathrm{O}\right)$ through the use of hydroxyl radicals $(\mathrm{OH} \bullet)$ as the principal species for the complete

\footnotetext{
* Corresponding author. Tel/Fax: +86-571-87953088; E-mail: haiqiangwang@zju.edu.cn

This work was supported by the National Key Research and Development Plan of China (2016YFC0204700), National Natural Science Foundation of China (NSFC-51578488), Zhejiang Provincial “151” Talents Program (2013), Key Project of Zhejiang Provincial Science and Technology Program, the Program for Zhejiang Leading Team of S\&T Innovation (2013TD07), and the Changiang Scholar Incentive Program (2009).

DOI: 10.1016/S1872-2067(18)63185-7 | http://www.sciencedirect.com/science/journal/18722067 | Chin. J. Catal., Vol. 40, No. 5, May2019
} 
oxidization of VOCs. However, the application of the PCO process is limited by its low quantum efficiency, a fast recombination of the electron-hole pairs, and photocatalyst deactivation during a lengthy operation time [15,18-20].

The combination of NTP and PCO as a way to deal with VOCs has recently attracted significant attention [1,21-26] because both technologies can be applied under ambient temperature and atmospheric pressure. Previous studies have emphasized that such a combination can improve the removal efficiency of VOCs and prompt the formation of carbon dioxide $[22,25,27,28]$. Although the generated ozone is the main oxidizer in a combined system, the residual ozone is a serious problem with regard to plasma $[1,25,29]$. Previous researches have mainly focused on the degradation efficiency of VOCs, and few studies have paid attention to the mineralization rate of VOCs in the entire system. Moreover, the ozone consumption in a combined system has not been clearly studied, and what role ozone plays in the combined system has yet to be well determined.

In this study, the NTP and PCO processes were combined to achieve a degradation of gas-phase toluene, which is a representative VOC that occurs from architectural coatings, motor vehicles, and various industrial processes [11,21,23,30,31]. Anatase $\mathrm{TiO}_{2}$ with a mesoporous network was synthesized for use as a photocatalyst owing to its physical and chemical stability, high photocatalytic activity, non-toxicity, and low cost [18-20]. The combination of NTP and PCO was achieved by placing a PCO reactor with an external UV lamp downstream from the NTP reactor with the aim of the better control and utilization of ozone $[1,23,24,26]$. The performances of sole $\left(\mathrm{O}_{3}\right.$, $\mathrm{UV}, \mathrm{NTP}$, and PCO $)$ and combined $\left(\mathrm{O}_{3}+\mathrm{TiO}_{2}, \mathrm{O}_{3}+\mathrm{UV}\right.$, NTP + UV, $\mathrm{O}_{3}+\mathrm{PCO}$, and NTP + PCO) processes were studied for comparison. The toluene removal efficiency, mineralization rate of toluene, generation of by-products, ozone utilization efficiency, and carbon balance of the system were investigated to explore the synergetic effect in the combined system and the role that ozone plays.

\section{Experimental}

\subsection{Setup}

The experimental setup was composed of four parts: polluted gas flow generation, an NTP reactor, a PCO reactor, and an analysis system. A schematic diagram of the experimental setup is shown in Fig. 1. The PCO reactor with a mercury lamp is placed downstream from the NTP reactor. The off-gas was analyzed using a gas chromatograph (GC), an ozone analyzer, and an FT-IR spectrometer.

\subsubsection{Polluted gas flow generation}

A polluted gas flow was generated through the blending of $\mathrm{N}_{2}$ (78 vol\%), $\mathrm{O}_{2}$ (21 vol\%), water vapor, and gas-phase toluene. A total flow rate of $2 \mathrm{~L} / \mathrm{min}$ was controlled using mass flow meters. Water was used for bubbling, whereas toluene was used for stripping. The concentration of the gas-phase toluene was adjusted to $70 \mathrm{ppm}$.

\subsubsection{NTP reactor}

The NTP reactor adopted a dielectric barrier discharge (DBD) to generate plasma. The DBD generator consisted of a quartz glass plate (as a dielectric), a copper plate (as a high-voltage electrode), and a stainless steel net (as a grounded electrode). The DBD plasma was generated using a home-made pulsed power supply, and the power supply, which was based on fast MOSFETs, produced high-voltage pulses with a peak voltage of up to $6 \mathrm{kV}$ and a width of $1-4 \mu \mathrm{s}$ at a repetition rate of up to $30 \mathrm{kHz}$ [11].

\subsubsection{PCO reactor}

The PCO reactor was designed to be baffled with the reaction area uniformly divided into four parts, each of which was $10 \mathrm{~cm} \times 4 \mathrm{~cm} \times 1.5 \mathrm{~cm}$ (length $\times$ width $\times$ height) in size. As an appropriate dose, $0.15 \mathrm{~g}$ of a catalyst was loaded onto a frosted glass using a dip-coating method. A $125 \mathrm{~W}$ high-pressure mercury lamp with a dominant wavelength of $365 \mathrm{~nm}$ was adopted as the external UV light source.

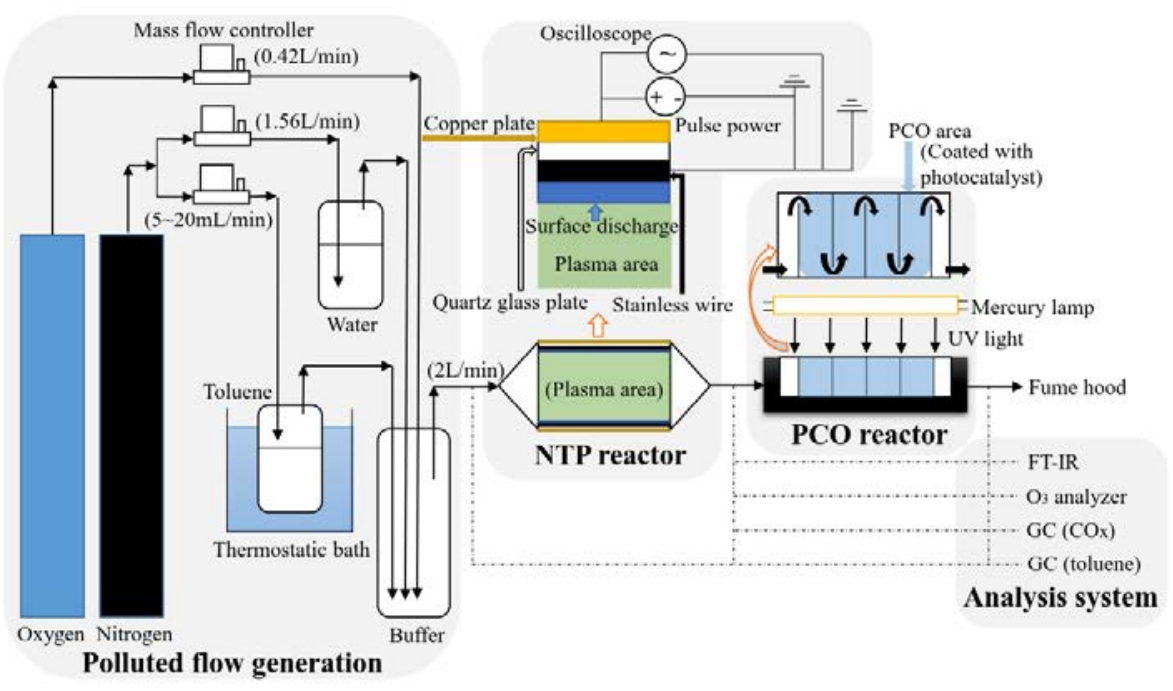

Fig. 1. Schematic diagram of experimental setup. 


\subsubsection{Analysis system}

Fourier transform infrared spectroscopy (FT-IR) was applied using a Bruker ALPHA-G spectrometer (Bruker, Germany). The concentrations of the gas-phase toluene, carbon monoxide, and carbon dioxide were monitored using GC (PuxiG5, China) with two flame ionization detectors and a nickel conversion equipment. The concentration of the ozone was detected using an ozone analyzer (UV 100, Eco Sensors, USA).

The off-gas containing various gaseous products was captured using an adsorption tube (Tenax TA/Tenax GR). The adsorbed compounds were identified using gas chromatograph-mass spectrometry (GC-MS, Agilent 7890A GC, equipped with an Agilent 5975C MS). The atomic ratio of the catalyst was measured using X-ray photoelectron spectroscopy (XPS, Thermo ESCALAB 250) with Al $K_{\alpha}$ X-ray radiation at $150 \mathrm{~W}$ as the excitation source. The species of the intermediates on the surface were tested using temperature programmed desorption-mass spectrometry (TPD-MS, TP-5079, Tianjin, Xianquan, equipped with a HIDEN QGA portable MS).

\subsection{Catalyst preparation}

$\mathrm{TiO}_{2}$ was synthesized using a one-step hydrothermal method. $2 \mathrm{~g}$ of $\mathrm{TiOSO}_{4} \cdot \mathrm{xH}_{2} \mathrm{SO}_{4} \cdot \mathrm{xH}_{2} \mathrm{O}$ powder was added into $60 \mathrm{~mL}$ of tert-butyl alcohol, followed by the addition of $1 \mathrm{~mL}$ of benzyl alcohol. The above suspension was magnetically stirred for 30 min. The precursor solution was then transferred into a 100-mL autoclave to achieve a reaction, which was maintained at $110{ }^{\circ} \mathrm{C}$ for $48 \mathrm{~h}$. The product was filtered, washed thoroughly with deionized water, and finally dried at $60^{\circ} \mathrm{C}$ for $6 \mathrm{~h}[32,33]$.

\subsection{Catalytic reaction}

After the gas-phase toluene achieved adsorption equilibrium and remained stable at $70 \mathrm{ppm}$, the performances of the sole $\left(\mathrm{O}_{3}, \mathrm{UV}\right.$, NTP, and PCO) and combined $\left(\mathrm{O}_{3}+\mathrm{TiO}_{2}, \mathrm{O}_{3}+\mathrm{UV}\right.$, $\mathrm{NTP}+\mathrm{UV}, \mathrm{O}_{3}+\mathrm{PCO}$, and NTP + PCO) processes were tested. In the sole process of $\mathrm{O}_{3}, \mathrm{O}_{3}$ was generated using NTP, and the concentrations of toluene at the inlet and outlet of the PCO reactor (without UV-irradiation or a photocatalyst) were detected. In the sole process of NTP, the concentrations of toluene at the inlet and outlet of the NTP reactor were detected when the DBD was on work. Thus, for $\mathrm{O}_{3}$ and NTP, it was necessary to turn on the power to generate the discharge and adjust the specific input energy. For the sole processes of UV and PCO, the mercury lamp was turned on to launch UV light, and the concentrations of toluene at the inlet and outlet of the PCO reactor (with or without a photocatalyst loaded) were detected. For the combined processes, two types of sole processes, namely, $\mathrm{O}_{3}$ and NTP, and UV and PCO, were coupled. Therefore, the combined processes included $\mathrm{O}_{3}+\mathrm{TiO}_{2}, \mathrm{O}_{3}+\mathrm{UV}, \mathrm{NTP}+\mathrm{UV}, \mathrm{O}_{3}+$ PCO, and NTP + PCO.

In the decomposition of gas-phase toluene, the toluene removal efficiency was calculated to evaluate the performance of toluene removal through the following equation:

Toluene removal efficiency $(\%)=\frac{[\text { toluene }]_{\text {inlet }}-[\text { toluene }]_{\text {outlet }}}{[\text { toluene }]_{\text {inlet }}} \times 100 \%$
The selectivity of $\mathrm{CO}_{x}\left(\mathrm{CO}\right.$ and $\left.\mathrm{CO}_{2}\right)$ was calculated as follows:

Selectivity of $\mathrm{CO}_{x}(\%)=\frac{\left[C O_{x}\right]_{\text {outlet }} \times 100 \%}{7 \times\left([\text { toluene }]_{\text {inlet }}-[\text { toluene }]_{\text {outlet }}\right)}(x=1,2)$

The mineralization rate, which represented the complete conversion of toluene into $\mathrm{CO}_{2}$, was calculated as follows:

$$
\text { Mineralization rate }(\%)=\frac{\left[\mathrm{CO}_{2}\right]_{\text {outlet }}}{7 \times[\text { toluene }]_{\text {inlet }}} \times 100 \%
$$

The ozone utilization efficiency was adopted to assess the extent of ozone utilization in the combined process, and was calculated as follows:

Ozone utilization efficiency $(\%)=\frac{[\text { ozone }]_{\text {inlet }}-[\text { ozone }]_{\text {outlet }}}{[\text { ozone }]_{\text {inlet }}} \times 100 \%$

During the NTP process, the specific input energy (SIE) was an important indicator reflecting the energy consumption. The injected energy per cycle (E) was determined through an integration of the product of the current and voltage. Thus, the injected power (P) and SIE were further calculated as follows [11]:

$$
\begin{gathered}
E(J)=\int_{0}^{T} u(t) \times i(t) d t \\
P(W)=E(J) \times \text { frequency }(\mathrm{Hz}) \\
\operatorname{SIE}(J / L)=P(W) \times 60 / Q(L / \mathrm{min})
\end{gathered}
$$

By adjusting the applied voltage, the SIE was adjusted to an appropriate value of $60 \mathrm{~J} / \mathrm{L}$.

\section{Results and discussion}

\subsection{Study on toluene degradation performance}

\subsubsection{Degradation performance of sole process}

First, a blank test was carried out to investigate the effects of the photolysis (UV) and ozonation $\left(\mathrm{O}_{3}\right)$ on the degradation of toluene. The results shown in Fig. 2 indicate that individual UV-irradiation or ozone had almost no effect on the toluene removal. The toluene degradation performances of sole NTP and PCO are also shown in Fig. 2. The performance of the NTP showed that the toluene removal efficiency remained relatively stable at $18.8 \%$ during the entire reaction time. In the plasma, highly reactive radical species such as $\mathrm{e}^{-}, \mathrm{O} \bullet, \mathrm{HO}_{2} \bullet, \mathrm{OH} \bullet, \mathrm{N}_{2} \bullet$, and $\mathrm{O}_{3}$ were generated, which could react with toluene. Nevertheless, the performance concluded that NTP exhibited low efficiency in terms of toluene removal under a low energy input. The performance of PCO showed that the toluene removal efficiency was only $13.4 \%$ on average. In the PCO, the generation of electron-hole pairs was a crucial step for forming active species such as hydroxyl radicals $(\mathrm{OH} \bullet)$ and superoxide radicals $\left(\mathrm{O}_{2}^{-} \bullet\right)$, which were principal species to react with toluene. The process is as follows:

$$
\begin{gathered}
\mathrm{TiO}_{2}+h v \rightarrow \mathrm{TiO}_{2}+e^{-}+h^{+} \\
h^{+}+\mathrm{H}_{2} \mathrm{O} \rightarrow \mathrm{OH} \cdot+H^{+} \\
h^{+}+\mathrm{OH}^{-} \rightarrow \mathrm{OH} . \\
e^{-}+\mathrm{O}_{2} \rightarrow \mathrm{O}_{2}^{-} .
\end{gathered}
$$

The performance indicates that PCO also exhibited low efficiency in terms of toluene removal, which might suffer from 


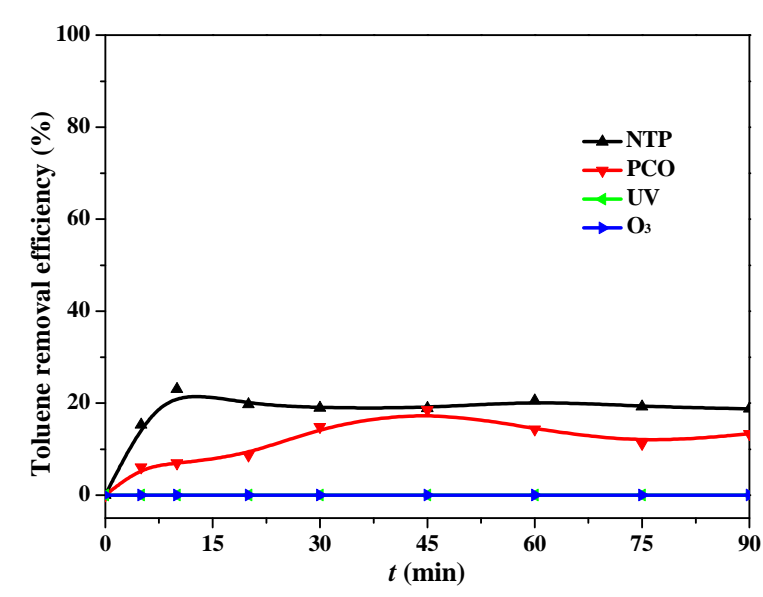

Fig. 2. Toluene degradation performance of sole processes.

limitations of the low quantum efficiency and the recombination of electrons and holes.

\subsubsection{Degradation performance of combined process}

Owing to the complicated factors of the combined NTP + PCO process, which includes free radical ions excited by the NTP, UV-irradiation in the PCO, the photocatalyst, and ozone generated in the NTP, multiple combined processes take place in the system, including catalytic ozonation $\left(\mathrm{O}_{3}+\mathrm{TiO}_{2}\right)$, ozone photolysis $\left(\mathrm{O}_{3}+\mathrm{UV}\right)$, NTP-assisted photolysis $(\mathrm{NTP}+\mathrm{UV})$, ozone-assisted PCO $\left(\mathrm{O}_{3}+\mathrm{PCO}\right)$, and the combined NTP + PCO process (NTP + PCO) $[23,30]$. Toluene degradation of these combined processes is shown in Fig. 3.

Contrary to previous research $[23,30]$, catalytic ozonation exhibited little activity regarding the degradation of toluene. This might be ascribed to the high flow rate in our system and the different catalyst loading method applied. Thus, the contribution of catalytic ozonation can be nearly neglected in this study. With ozone and NTP-assisted photolysis, the toluene removal efficiency reached $43.6 \%$ and $53.8 \%$, respectively, revealing that ozone photolysis might exert an important impact on the toluene removal. Furthermore, the toluene removal efficiency reached $76.5 \%$ and $80.2 \%$ in the ozone- and

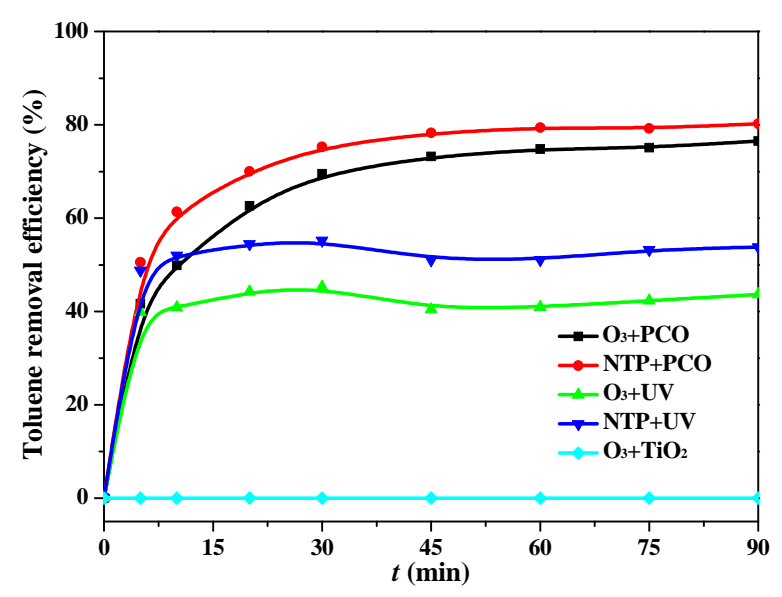

Fig. 3. Toluene degradation performance of combined processes.
NTP-assisted PCO, which were much higher than that of NTP, PCO, ozone photolysis, and NTP-assisted photolysis. This result indicates that the participation of ozone in the photocatalytic process contributes significantly to the degradation of toluene, and the ozone creates an intimate bond between the NTP and PCO processes.

If the NTP and PCO processes are simply coupled together, the toluene removal efficiency can be calculated approximately as follows:

$$
1-\left(1-\eta_{1}\right)\left(1-\eta_{2}\right)=\eta_{1}+\eta_{2}-\eta_{1} \eta_{2}=29.7 \%,
$$

where $\eta_{1}$ refers to the toluene removal efficiency of NTP (18.8\%), and $\eta_{2}$ refers to that of PCO (13.4\%). Actually, a distinct enhancement was obtained through the removal of toluene in the combined NTP + PCO process. The toluene removal efficiency reached $80.2 \%$, which was even much greater than the sum of NTP (18.8\%) and PCO (13.4\%). This indicates that a strong synergetic effect exists in the combined process of NTP and PCO for toluene removal.

\subsection{Study on comprehensive degradation performance}

\subsubsection{Selectivity of $\mathrm{CO}_{x}$ and mineralization}

Extensive attention has been paid to the selectivity of $\mathrm{CO}_{2}$ and mineralization of VOCs $[2,3,9,11,34]$. In this study, the selectivity of $\mathrm{CO}_{x}$ was calculated to explore whether the removed toluene was completely converted into $\mathrm{CO}$ or $\mathrm{CO}_{2}$. The carbon balance was carefully calculated to estimate the amount of exhausted carbon-based intermediates in the gas phase. A comparison of the carbon balance among the above processes is shown in Fig. 4(A), followed by the mineralization rate shown in Fig. 4(B).

In the NTP process, the selectivity of $\mathrm{CO}_{x}$ was close to $100 \%$ owing to the carbon balance calculation, indicating that the removed toluene was almost completely decomposed into CO and $\mathrm{CO}_{2}$. However, the selectivity of $\mathrm{CO}$ was the highest among the tested processes, whereas the selectivity of $\mathrm{CO}_{2}$ was $70 \%$. This illustrates that a portion of the toluene did not achieve deep oxidation, and only oxidized into CO in the NTP. In the PCO, the selectivity of $\mathrm{CO}_{x}$ was clearly lower than that of the NTP, indicating that a greater amount of carbon-based intermediates was generated during the photocatalytic degradation process. Many studies have reported that intermediates such as benzaldehyde, benzyl alcohol, and benzoic acid might be generated $[30,35,36]$. However, the selectivity of $\mathrm{CO}_{2}$ during the PCO process was higher than that of the NTP, indicating that CO was easier to be oxidized into $\mathrm{CO}_{2}$ through this process. In the ozone-assisted PCO and combined NTP + PCO processes, the selectivity of $\mathrm{CO}_{2}$ was greater than that of the sole NTP and PCO processes, whereas the generation of intermediates also showed the lowest value. It can be concluded that most of the degraded toluene was converted into $\mathrm{CO}_{2}$.

For a deeper understanding of the performance of ozoneand NTP-assisted photolysis, the selectivity of $\mathrm{CO}_{x}$ was also determined. The selectivity of $\mathrm{CO}_{2}$ was much lower, whereas the generation of intermediates appeared to be significantly larger in comparison with the other processes. This indicates that a large portion of toluene was converted into carbon-based 

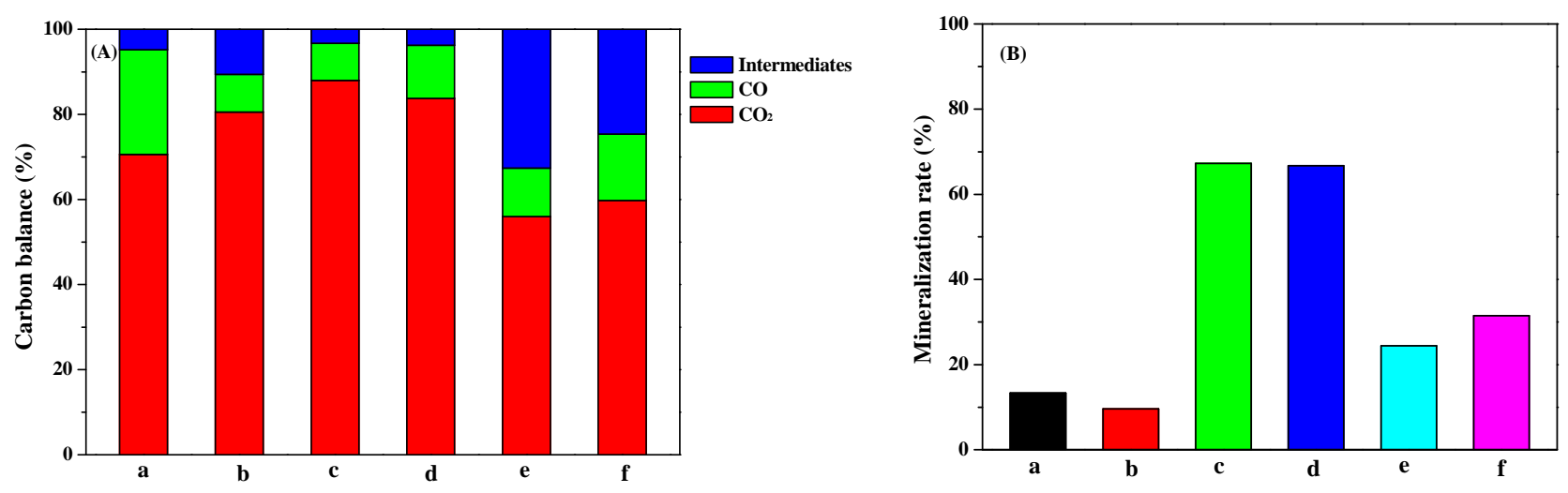

Fig. 4. Selectivity of $\mathrm{CO}_{x}(\mathrm{~A})$ and mineralization rate (B) of different processes. (a) NTP; (b) PCO; (c) $\mathrm{O}_{3}+$ PCO; (d) NTP + PCO; (e) $\mathrm{O}_{3}+\mathrm{UV}$; (f) NTP + UV.

intermediates during the ozone and NTP-assisted photolysis processes, instead of $\mathrm{CO}$ or $\mathrm{CO}_{2}$.

In terms of the mineralization rate, among the tested processes, the ozone-assisted PCO and combined NTP + PCO system also showed the best performances. This indicates that a strong synergetic effect of NTP and PCO, which is mainly contributed to by ozone, not only influences the toluene removal efficiency, but also affects the selectivity of $\mathrm{CO}_{x}$ and the mineralization rate.

\subsubsection{Ozone utilization}

Ozone generated in the NTP is considered to have a longer lifetime than other radical species, which was also deemed a type of harmful by-product owing to its leakage in the exhausted gases. Ozone was formed through oxygen radicals combined with oxygen molecules as follows [37]:

$$
\begin{gathered}
e^{-}+\mathrm{O}_{2} \rightarrow e^{-}+\mathrm{O} \cdot+\mathrm{O} . \\
\mathrm{O} \cdot+\mathrm{O}_{2}+\text { extra energy } \rightarrow \mathrm{O}_{3}
\end{gathered}
$$

A blank test was carried out when the gas flow of pure air (without toluene) passed the NTP reactor, which was turned on. The concentration of ozone gradually and steadily approached $340 \mathrm{ppm}$, which is denoted as the concentration of ozone at the inlet. The ozone utilization efficiency during the ozone-related processes is shown in Fig. 5.

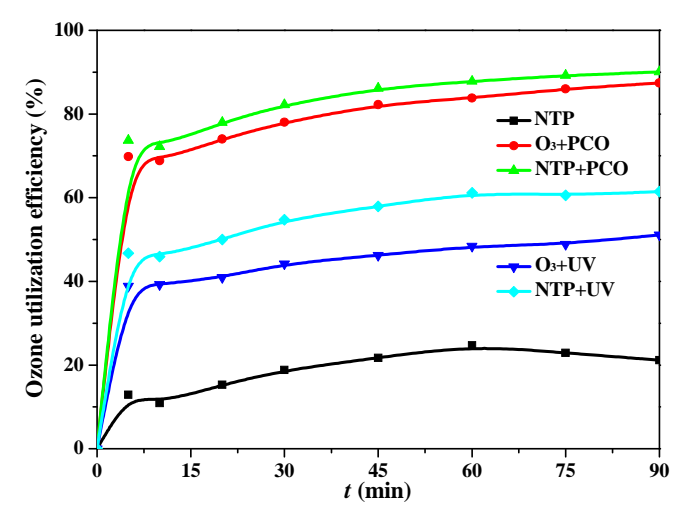

Fig. 5. Ozone utilization efficiency of ozone-related processes.
The ozone utilization efficiency of the NTP was shown to be only $21.2 \%$, which is the lowest among these processes. It is concluded that ozone has seldom been utilized in the NTP process, which might be ascribed to the short duration time of the NTP process. For the ozone and NTP-assisted photolysis processes, the ozone utilization efficiency arrived at $51.1 \%$ and $61.5 \%$, respectively. Although the performance was significantly improved compared with that of the NTP, a large amount of ozone was still emitted in the off-gas. During the ozone-assisted PCO and combined NTP + PCO processes, the ozone utilization efficiency reached approximately $87.4 \%$ and $90.1 \%$, indicating that ozone was efficiently utilized during the toluene degradation process.

These results further indicate that the synergetic effect of NTP and PCO is comprehensive, which is reflected in the toluene removal efficiency, the selectivity of $\mathrm{CO}_{x}$, the mineralization rate, and the ozone utilization performance. It also indicates that a strong synergetic effect occurs among the coexistence of ozone, UV-irradiation, and the photocatalyst. The results are also consistent with the report indicating that the toluene oxidation rate, $\mathrm{CO}_{2}$ yield rate, and ozone removal efficiency in the $\mathrm{UV} / \mathrm{O}_{3} / \mathrm{TiO}_{2}$ process are greater than those in the $\mathrm{UV} / \mathrm{O}_{3}$ process [21]. The results are also identical with previous research $[23,30,38,39]$.

\subsection{By-products in the gas phase}

\subsubsection{Analysis of FT-IR spectra}

To further understand the synergetic effect of NTP + PCO, an FT-IR spectrometer analysis was applied to test the by-products generated during the toluene degradation process, the results of which are shown in Fig. 6.

Fig. 6(a) shows the FT-IR spectra of toluene. The bands appearing at 3013 and $2941 \mathrm{~cm}^{-1}$ were assigned to the $\mathrm{C}-\mathrm{H}$ stretching mode of the aromatic ring and methyl group, respectively. The bands at 1611 and $1499 \mathrm{~cm}^{-1}$ were assigned to the skeleton vibrations of the aromatic ring $[40,41]$. The band located at $728 \mathrm{~cm}^{-1}$ can be identified as toluene as well. In the spectra of the exhausted gases of the NTP (Fig. 6(b)) and combined NTP + PCO (Fig. 6(c)) processes, the above-mentioned bands decreased and even disappeared, indicating that the 


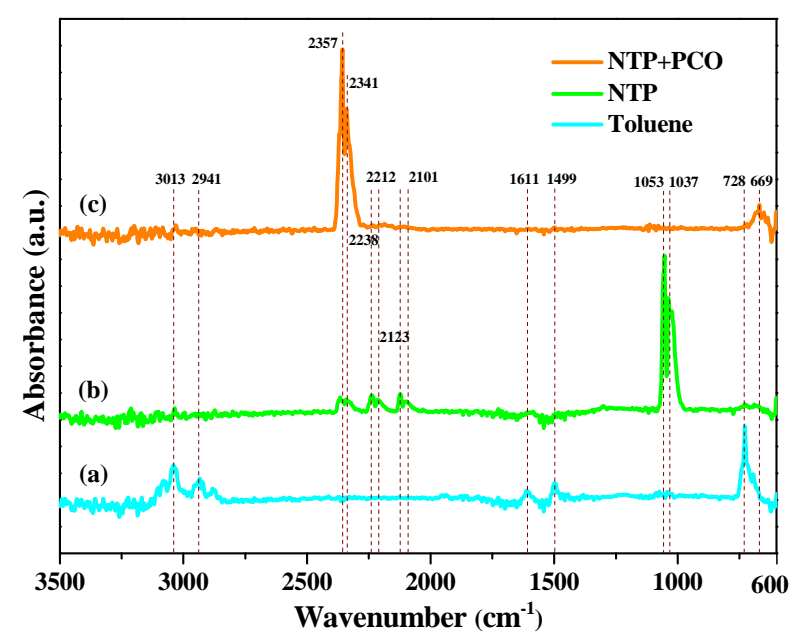

Fig. 6. FT-IR spectra of toluene (a), NTP (b), and combined NTP + PCO (c) processes regarding the degradation of toluene.

toluene was dramatically degraded. In the spectrum for the exhausted gases from the NTP process (Fig. 6(b)), bands at 1053 and $1037 \mathrm{~cm}^{-1}$ for ozone [42] sharply emerged, indicating that a significant amount of ozone was generated and emitted. Weak bands appearing at 2357 and $2341 \mathrm{~cm}^{-1}$ were assigned to $\mathrm{CO}_{2}$, whereas those at 2123 and $2101 \mathrm{~cm}^{-1}$ were assigned to $\mathrm{CO}$ [43], indicating that a proportion of the toluene was oxidized into $\mathrm{CO}$ and $\mathrm{CO}_{2}$. In addition, the small bands at 2238 and 2212 $\mathrm{cm}^{-1}$ were assigned to $\mathrm{N}_{2} \mathrm{O}$ [44], which is a by-product of the plasma process. In the spectrum of the exhausted gases from the combined NTP + PCO process (Fig. 6(c)), the bands at 2357 and $2341 \mathrm{~cm}^{-1}$ are attributed to $\mathrm{CO}_{2}$, which became much stronger in comparison with the sole processes, whereas the bands at 2238 and $2212 \mathrm{~cm}^{-1}\left(\mathrm{~N}_{2} \mathrm{O}\right) 2123$ and $2101 \mathrm{~cm}^{-1}$ (CO) and 1053 and $1037 \mathrm{~cm}^{-1}\left(\mathrm{O}_{3}\right)$ disappeared. The new band at $669 \mathrm{~cm}^{-1}$ attributed to $\mathrm{CO}_{2}$ [43], appeared when $\mathrm{CO}_{2}$ was present at a high concentration. This indicates that toluene is dramatically oxidized into $\mathrm{CO}_{2}$ through the combined NTP + PCO process. Ozone was fully taken advantage of in the arrangement of the PCO downstream NTP. In addition, by-products such as $\mathrm{N}_{2} \mathrm{O}$ and $\mathrm{CO}$ were also effectively removed. To summarize, the combined NTP + PCO process exhibited high efficiency in terms of the degradation of toluene into $\mathrm{CO}_{2}$.

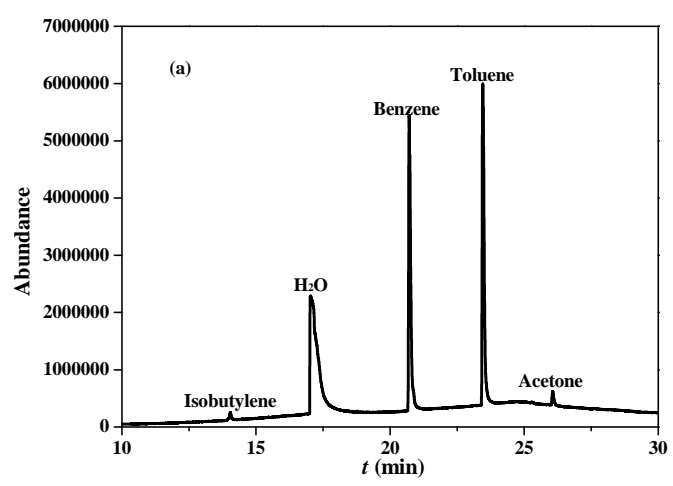

\subsubsection{Analysis of GC-MS spectra}

Further, GC-MS was adopted to identify the by-products in the exhausted gases during the gas phase. The results of NTP-assisted photolysis and the combined NTP + PCO process were analyzed for comparison, the results of which are shown in Fig. 7.

As shown in Fig. 7(a), a sharp peak of benzene appears next to the peaks of toluene, $\mathrm{CO}_{2}$, and $\mathrm{H}_{2} \mathrm{O}$. In addition, small peaks of isobutylene and acetone also appear. This indicates that a portion of the degraded toluene was not completely oxidized into $\mathrm{CO}_{2}$ and $\mathrm{H}_{2} \mathrm{O}$, but was converted into benzene and small amounts of isobutylene and acetone during the NTP-assisted photolysis. In contrast, Fig. 7(b) shows that the peak of benzene decreased dramatically, indicating that the removed toluene was almost completely oxidized into $\mathrm{CO}_{2}$ and $\mathrm{H}_{2} \mathrm{O}$ during the combined NTP + PCO process. These results correspond well with the selectivity of $\mathrm{CO}_{x}$.

\subsection{Adsorbed intermediate products on catalyst surface}

\subsubsection{Analysis of XPS}

Clearly, the apparent color of the $\mathrm{TiO}_{2}$ photocatalysts changed after the above toluene degradation processes were applied. The color of the pure $\mathrm{TiO}_{2}$ was white. The color of the used photocatalyst changed thoroughly into yellow during the PCO process (called $\mathrm{PCO}-\mathrm{TiO}_{2}$ herein) and changed slightly into yellow during the combined NTP + PCO process (called combined- $\mathrm{TiO}_{2}$ ). This clearly indicates that some intermediates were adsorbed on the surface of the $\mathrm{TiO}_{2}$ and were not desorbed in time. A type of in situ treatment was introduced in our study. The flow of toluene was cut off, and only air continued to flow through. Both NTP and PCO were turned on. The apparent color of $\mathrm{PCO}-\mathrm{TiO}_{2}$ returned to white after the in situ treatment (called treated- $\mathrm{TiO}_{2}$ ). The result of apparent colors of the samples was shown in Fig. 8.

To find the differences among the four samples above, an XPS was conducted to analyze the atomic ratios of Ti on the catalyst surface. The results are shown in Table 1 . The atomic ratios of $\mathrm{Ti} 2 p$ were $19.10 \%, 17.77 \%, 18.16 \%$, and $18.26 \%$, respectively. The smaller the atomic ratio of Ti $2 p$ was, the greater the amount of carbon-based intermediates that were deposited onto the surface of the sample. These results indicate

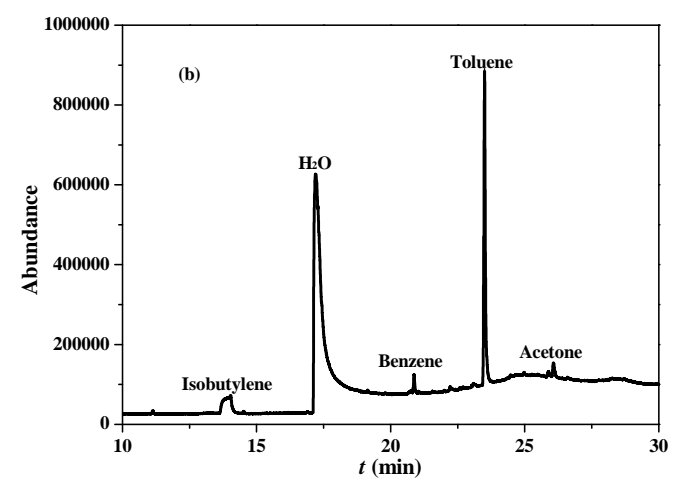

Fig. 7. GC-MS spectra of the exhausted gases of NTP + UV (a) and NTP + PCO (b) processes. 
Table 1

XPS analysis results (atomic ratio of Ti of the four samples).

\begin{tabular}{lcccc}
\hline Atomic \% & Pure $^{-\mathrm{TiO}_{2}}$ & $\mathrm{PCO}-\mathrm{TiO}_{2}$ & Combined-TiO & Treated-TiO \\
\hline $\mathrm{Ti} 2 p$ & 19.10 & 17.77 & 18.16 & 18.26 \\
\hline
\end{tabular}

that some carbon-based intermediates were deposited onto the $\mathrm{TiO}_{2}$ during the PCO and combined NTP + PCO processes. The deposition of carbon-based intermediates during the PCO process was more severe. During the combined NTP + PCO process, fewer intermediates were deposited onto the photocatalyst surface, whereas the atomic ratio of Ti $2 p$ of the treated- $\mathrm{TiO}_{2}$ was greater than that of $\mathrm{PCO}-\mathrm{TiO}_{2}$ and combined-TiO indicating that carbon-based intermediates on the catalyst were decomposed to a certain degree. These results are consistent with previous research [26].

\subsubsection{Analysis of TPD-MS}

Previous studies have reported that benzaldehyde, benzyl alcohol, benzoic acid, benzene, phenol, and acetone are the most common intermediates in the photocatalytic oxidation of toluene $[30,35,36,45,46]$. To determine the specific species deposited on the surface of a photocatalyst, TPD-MS was adopted for a semi-quantitative analysis to test the amounts of the above compounds. The above four samples were analyzed, the results of which are shown in Fig. 9.

Fig. 9(a) shows that the compounds were not present on the surface of the pure $\mathrm{TiO}_{2}$. Fig. 9(b) indicates that benzene and acetone were the main intermediates deposited onto the surface of $\mathrm{TiO}_{2}$ during the PCO process, whereas toluene, phenol, benzaldehyde, benzyl alcohol, and benzoic acid were scarcely detected. This indicates that intermediates such as benzene and acetone ultimately accumulated on the surface of the $\mathrm{TiO}_{2}$. Fig. 9(c) showed that the peaks of benzene and acetone decreased significantly compared with that of $\mathrm{PCO}-\mathrm{TiO}_{2}$, revealing that smaller amounts of benzene and acetone were accumulated on $\mathrm{TiO}_{2}$ during the combined NTP + PCO process. Fig. 9(d) shows that the amounts of benzene and acetone were further decreased during the treatment process, demonstrating that the intermediates on $\mathrm{TiO}_{2}$ can be decomposed during the NTP and UV-irradiation processes.

\subsection{Role of ozone}

During the combined NTP + PCO process, the degradation reaction took place separately within the plasma and photocatalytic regions. The free radical species generated in the plasma region had a short life expectancy. Only the by-product

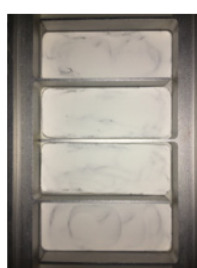

Pure $\mathrm{TiO}_{2}$

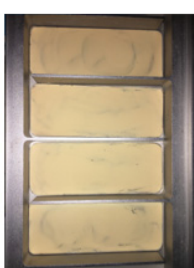

$\mathrm{PCO}_{\mathrm{TiO}}$

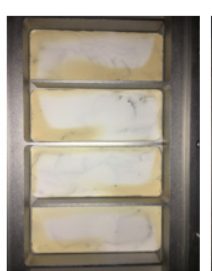

Combined-TiO

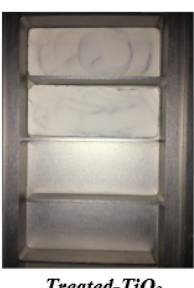

Treated-TiO
Fig. 8. Apparent colors of the samples. of $\mathrm{O}_{3}$ was able to cover the plasma and photocatalytic regions. Thus, it can be concluded that ozone had a significant contribution to the synergetic effect of NTP and PCO for the enhancement of the toluene removal efficiency, the selectivity of $\mathrm{CO}_{x}$, and the rate of mineralization. There are two prevailing ideas explaining the contribution of ozone [24,26,30,38].

As the first idea, ozone might be decomposed through the absorption of photons in the following pathway:

$$
\mathrm{O}_{3}+h v \rightarrow \mathrm{O}+\mathrm{O}_{2}
$$

here, $\mathrm{O} \bullet$ is generally regarded as an intermediate highly active oxygen species formed from the catalytic and photolysis decomposition of ozone. It acts as a strong oxidant during the photocatalytic oxidation process. Some studies have reported that $0 \bullet$, acting as a strong oxidant, is beneficial for the photocatalytic oxidation of toluene $[23,30]$.

As the second idea, ozone might act as an electron acceptor during the photocatalytic process through the following pathway:

$$
\begin{gathered}
\mathrm{TiO}_{2}+h v \rightarrow \mathrm{TiO}_{2}+e^{-}+h^{+} \\
\mathrm{O}_{3}+e^{-} \rightarrow \mathrm{O}_{3}^{-} . \\
\mathrm{O}_{3}^{-} \cdot \rightarrow \mathrm{O}^{-} \cdot+\mathrm{O}_{2}
\end{gathered}
$$

The most important aspect is that the electron affinity of $\mathrm{O}_{3}$ $(2.1 \mathrm{eV})$ is much higher than that of $\mathrm{O}_{2}(0.44 \mathrm{eV})[21,28]$. Therefore, the electrons in the conduction band of $\mathrm{TiO}_{2}$ activated by UV light are easier to be captured by $\mathrm{O}_{3}$, and promote the formation of the highly oxidizing species $\mathrm{O}^{-} \bullet$. The process can also decrease the recombination rate of the electron-hole pairs by scavenging photo-induced electrons, thereby accelerating the generation rate of hydroxyl radicals [21,24,30]. The reactions might take the following pathway:

$$
\begin{aligned}
h^{+}+\mathrm{H}_{2} \mathrm{O} & \rightarrow \mathrm{OH} \cdot+\mathrm{H}^{+} \\
h^{+}+\mathrm{OH}^{-} & \rightarrow \mathrm{OH} . \\
\mathrm{H}^{+}+\mathrm{O}^{-} & \rightarrow \mathrm{OH} .
\end{aligned}
$$

The first idea considered above may be supported by the results of the NTP-assisted photolysis. When ozone absorbs photons and produces the active species of $0 \bullet, 0 \bullet$ can directly participate in the oxidation of toluene during the gas phase. The second idea may be supported based on the results of the combined NTP + PCO process. When the separated electrons are captured by ozone, more hydroxyl radicals are generated on the surface of $\mathrm{TiO}_{2}$ and participate in the oxidation of toluene. The above comparison indicates that the second idea appears to be more important. The contribution of ozone during photocatalytic oxidation is mainly as an electron acceptor and scavenger.

Based on a comparison of the degradation performance of different combined processes, it was concluded that the contribution of ozone in the combined NTP + PCO process was mainly its participation in the photocatalytic oxidation and its acting as an electron acceptor and scavenger, generating more hydroxyl radicals and reducing the recombination rate of electron-hole pairs. Only a small amount of ozone took part in the photolytic oxidation. The process can be described in Fig. 10 .

\section{Conclusions}

In this study, the combined NTP + PCO process was used for 

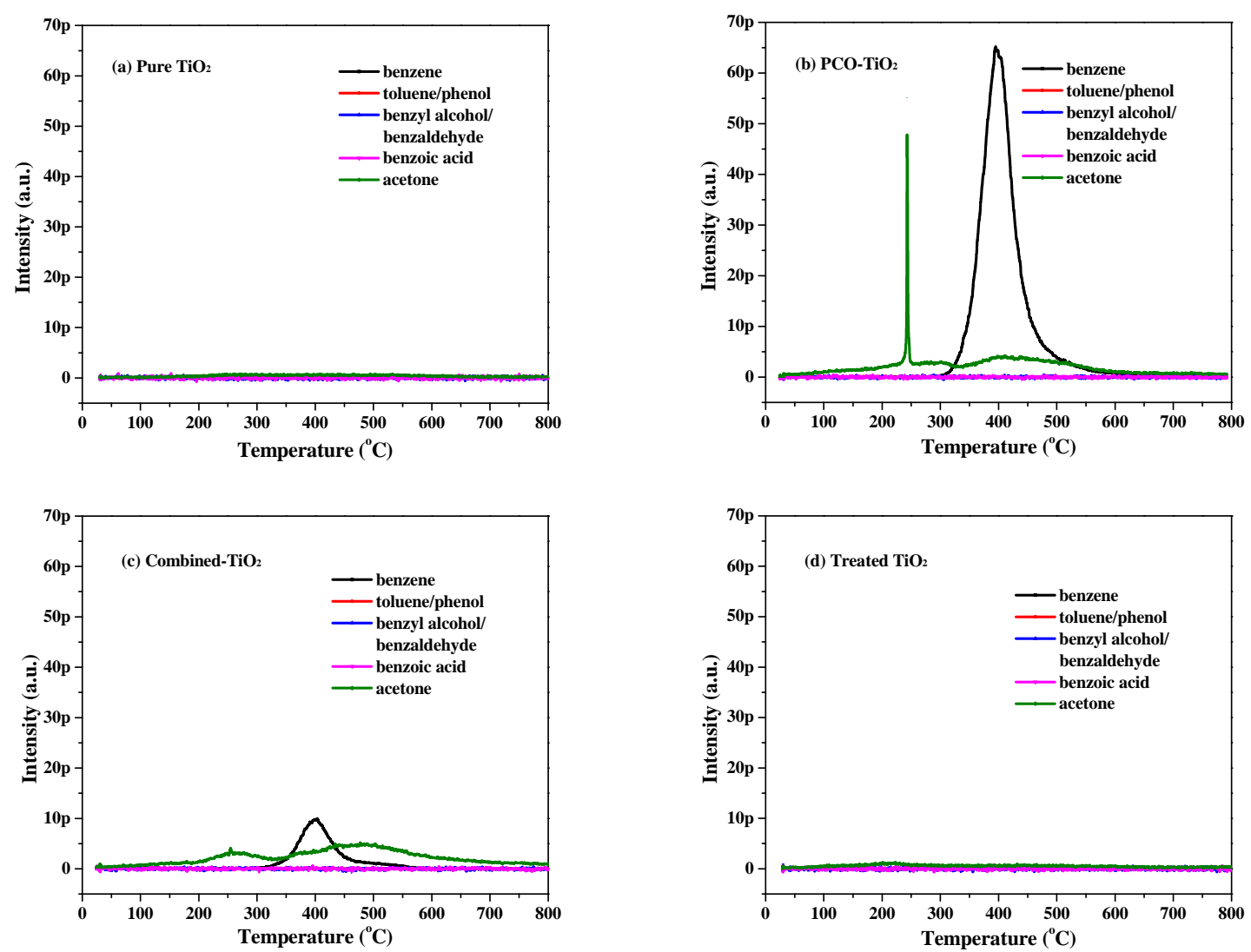

Fig. 9. TPD-MS spectra of the four samples.

the degradation of gas-phase toluene, and the degradation performances of sole $\left(\mathrm{O}_{3}, \mathrm{UV}, \mathrm{NTP}\right.$, and PCO $)$ and combined $\left(\mathrm{O}_{3}+\right.$ $\mathrm{TiO}_{2}, \mathrm{O}_{3}+\mathrm{UV}, \mathrm{NTP}+\mathrm{UV}, \mathrm{O}_{3}+\mathrm{PCO}$, and NTP + PCO) processes were all investigated to discover the synergetic effect between NTP and PCO.

Through a combination of NTP and PCO, a significant synergetic effect was obtained on the toluene removal efficiency, selectivity of $\mathrm{CO}_{x}$, mineralization rate, ozone utilization efficiency, and the generation of by-products. The toluene removal efficiency of the combined NTP + PCO process was $80.2 \%$, which was much greater than that of NTP (18.8\%) and PCO $(13.4 \%)$ alone. Furthermore, the mineralization rate, selectivity of $\mathrm{CO}_{x}$, and ozone utilization efficiency were $83.8 \%, 96.2 \%$, and $90.1 \%$, which were also significantly greater than those in the sole processes of NTP or PCO. The results of FT-IR and GC-MS

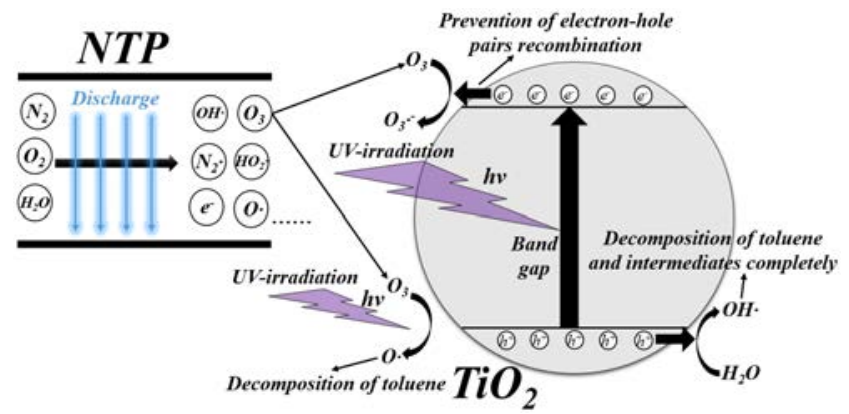

Fig. 10. Role of ozone in the combined NTP + PCO process. indicated that by-products in the gas phase were dramatically reduced and that the mineralization rate was significantly improved during the combined NTP + PCO process. Additionally, the combined NTP + PCO process can dramatically reduce the amount of carbon-based intermediates on $\mathrm{TiO}_{2}$ surface, such as benzene and acetone. It was also verified that the coexistence of UV-irradiation, ozone, and a catalyst can decrease the amount of carbon-based intermediates adsorbed on the catalyst surface. These results indicate that the emergence of ozone had a significant contribution to the performance enhancement, and was most likely to act as an electron acceptor and scavenger, generating more hydroxyl radicals and reducing the recombination rate of the electron-hole pairs.

\section{References}

[1] F. Ghorbani Shahna, A. Bahrami, I. Alimohammadi, R. Yarahmadi, B. Jaleh, M. Gandomi, H. Ebrahimi, K. Ad-Din Abedi, J. Hazard. Mater., 2017, 324, 544-553.

[2] H. B. Huang, H. L. Huang, Q. Y. Feng, G. Y. Liu, Y. J. Zhan, M. Y. Wu, H. X. Lu, Y. J. Shu, D. Y. C. Leung, Appl. Catal. B, 2017, 203, 870-878.

[3] Y. J. Shu, J. Ji, Y. Xu, J. G. Deng, H. B. Huang, M. He, D. Y. C. Leung, M. Y. Wu, S. W. Liu, S. L. Liu, G. Y. Liu, R. J. Xie, Q. Y. Feng, Y. J.Zhan, R. M. Fang, X. G. Ye, Appl. Catal. B, 2018, 220, 78-87.

[4] G. Y. Liu, J. Ji, H. B. Huang, R. J. Xie, Q. Y. Feng, Y. J. Shu, Y. J. Zhan, R. M. Fang, M. He, S. L. Liu, X. G. Ye, D. Y. C. Leung, Chem. Eng. J., 2017, $324,44-50$. 


\section{Graphical Abstract}

Chin. J. Catal., 2019, 40: 681-690 doi: 10.1016/S1872-2067(18)63185-7

\section{Synergetic effect between non-thermal plasma and photocatalytic oxidation on the degradation of gas-phase toluene: Role of ozone}

Haoling Ye, Yiqiu Liu, Si Chen, Haiqiang Wang *, Zhen Liu, Zhongbiao Wu

Zhejiang University; Zhejiang Provincial Engineering Research Center of Industrial Boiler \& Furnace Flue Gas Pollution Control

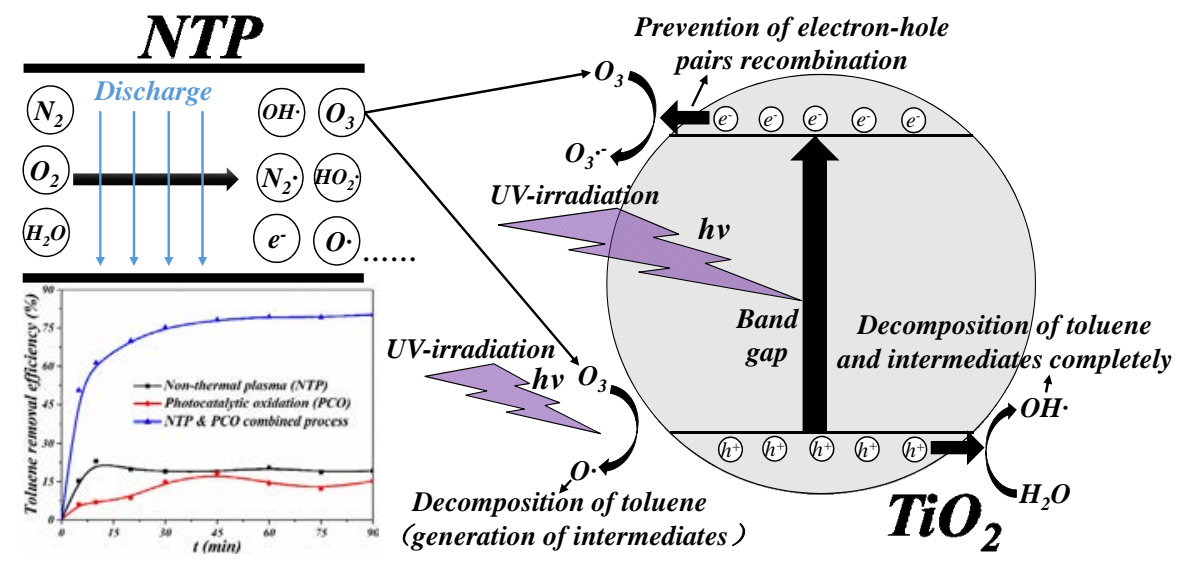

During the combined NTP + PCO process, ozone mainly acted as an electron acceptor and scavenger, generating more hydroxyl radicals and reducing the recombination of electron-hole pairs.

[5] W. B. Li, J. X. Wang, H. Gong, Catal. Today, 2009, 148, 81-87.

[6] P. Doggali, Y. Teraoka, P. Mungse, I. K. Shah, S. Rayalu, N. Labhsetwar, J. Mol. Catal. A, 2012, 358, 23-30.

[7] R. M. Fang, H. B. Huang, J. Ji, M. He, Q. Y. Feng, Y. J. Zhan, D. Y. C. Leung, Chem. Eng. J., 2018, 334, 2050-2057.

[8] Y. Z. Li, Z. Y. Fan, J. W. Shi, Z. Y. Liu, W. F. Shangguan, Chem. Eng. J., 2014, 241, 251-258.

[9] J. L. Wu, Q. B. Xia, H. H. Wang, Z. Li, Appl. Catal. B, 2014, 156, 265-272.

[10] E. C. Neyts, K. Ostrikov, M. K. Sunkara, A. Bogaerts, Chem. Rev., 2015, 115, 13408-13446.

[11] T. Wang, S. Chen, H. Q. Wang, Z. Liu, Z. B. Wu, Chin. J. Catal., 2017, 38, 793-804.

[12] A. M. Vandenbroucke, R. Morent, N. De Geyter, C. Leys, J. Hazard. Mater., 2011, 195, 30-54.

[13] S. Chen, H. Q. Wang, M. P. Shi, H. L. Ye, Z. B. Wu, Environ. Sci. Technol., 2018, 52, 8568-8577.

[14] O. Debono, V. Hequet, L. Le Coq, N. Locoge, F. Thevenet, Appl. Catal. $B, \mathbf{2 0 1 7}, 218,359-369$.

[15] A. H. Mamaghani, F. Haghighat, C. S. Lee, Appl. Catal. B, 2017, 203, 247-269.

[16] D. S. Selishchev, N. S. Kolobov, A. A. Pershin, D. V. Kozlov, Appl. Catal. B, 2017, 200, 503-513.

[17] S. Weon, J. Kim, W. Choi, Appl. Catal. B, 2018, 220, 1-8.

[18] Z. Shayegan, C. S. Lee, F. Haghighat, Chem. Eng. J., 2018, 334, 2408-2439.

[19] J. Schneider, M. Matsuoka, M. Takeuchi, J. L. Zhang, Y. Horiuchi, M. Anpo, D. W. Bahnemann, Chem. Rev., 2014, 114, 9919-9986.

[20] M. N. Lyulyukin, P. A. Kolinko, D. S. Selishchev, D. V. Kozlov, Appl. Catal. B, 2018, 220, 386-396.

[21] K. P. Yu, Grace W. M. Lee, Appl. Catal. B, 2007, 75, 29-38.

[22] O. Guaitella, F. Thevenet, E. Puzenat, C. Guillard, A. Rousseau, Appl.
Catal. B, 2008, 80, 296-305.

[23] H. B. Huang, D. Q. Ye, J. Hazard. Mater., 2009, 171, 535-541.

[24] A. Maciuca, C. Batiot-Dupeyrat, J. M. Tatibouët, Appl. Catal. B, 2012, 125, 432-438.

[25] A. A. Assadi, A. Bouzaza, C. Vallet, D. Wolbert, Chem. Eng. J., 2014, 254, 124-132.

[26] W. Abou Saoud, A. A. Assadi, M. Guiza, A. Bouzaza, W. Aboussaoud, A. Ouederni, I. Soutrel, D. Wolbert, S. Rtimi, Appl. Catal. B, 2017, 213, 53-61.

[27] F. Thevenet, O. Guaitella, E. Puzenat, J. M. Herrmann, A. Rousseau, C. Guillard, Catal. Today, 2007, 122, 186-194.

[28] J. Taranto, D. Frochot, P. Pichat, Ind. Eng. Chem. Res., 2007, 46, 7611-7614.

[29] S. Gharib-Abou Ghaida, A. A. Assadi, G. Costa, A. Bouzaza, D. Wolbert, Chem. Eng. J., 2016, 292, 276-283.

[30] H. B. Huang, W. B. Li, Appl. Catal. B, 2011, 102, 449-453.

[31] J. Kim, P. Y. Zhang, J. G. Li, J. L. Wang, P. F. Fu, Chem. Eng. J., 2014, $252,337-345$.

[32] Z. F. Bian, J. Zhu, J. Wen, F. L. Cao, Y. N. Huo, X. F. Qian, Y. Cao, M. Q. Shen, H. X. Li, Y. F. Lu, Angew. Chem. Int. Ed., 2011, 50, 1105-1108.

[33] Y. T. Peng, Z. Y. Le, M. C. Wen, D. Q. Zhang, Z. Chen, H. B. Wu, H. X. Li, Y. F. Lu, Nano Energy, 2017, 35, 44-51.

[34] Y. J. Zhan, J. Ji, H. B. Huang, M. He, D. Y. C. Leung, S. L. Liu, Y. J. Shu, Q. Y. Feng, R. J. Xie, R. M. Fang, X. G. Ye, Chem. Eng. J., 2018, 334, 1422-1429.

[35] J. H. Mo, Y. P. Zhang, Q. J. Xu, Y. F. Zhu, J. J. Lamson, R. Y. Zhao, Appl. Catal. B, 2009, 89, 570-576.

[36] C. L. Bianchi, S. Gatto, C. Pirola, A. Naldoni, A. Di Michele, G. Cerrato, V. Crocellà, V. Capucci, Appl. Catal. B, 2014, 146(SI), 123-130.

[37] A. M. Harling, D. J. Glover, J. C. Whitehead, K. Zhang, Appl. Catal. B, 2009, 90, 157-161.

[38] J. Ji, Y. Xu, H. B. Huang, M. He, S. L. Liu, G. Y. Liu, R. J. Xie, Q. Y. Feng, 
Y. J. Shu, Y. J. Zhan, R. M. Fang, X. G. Ye, D. Y. C. Leung, Chem. Eng. J., 2017, 327, 490-499.

[39] H. B. Huang, G. Y. Liu, Y. J. Zhan, Y. Xu, H. X. Lu, H. L. Huang, Q. Y. Feng, M. Y. Wu, Catal. Today, 2017, 281, 649-655.

[40] M. D. Hernández-Alonso, I. Tejedor-Tejedor, J. M. Coronado, M. A. Anderson, Appl. Catal. B, 2011, 101, 283-293.

[41] A. J. Maira, J. M. Coronado, V. Augugliaro, K. L. Yeung, J. C. Conesa, J. Soria, J. Catal., 2001, 202, 413-420.

[42] K. Skalska, J. S. Miller, S. Ledakowicz, Chem. Pap., 2011, 65,
193-197.

[43] I. Pitkanen, J. Huttunen, H. Halttunen, R. Vesterinen, J. Therm. Anal., 1999, 56, 1253-1259.

[44] J. O. Jo, Q. H. Trinh, S. H. Kim, Y. S. Mok, Catal. Today, 2017, 310(SI), $42-48$.

[45] M. Sleiman, P. Conchon, C. Ferronato, J. M. Chovelon, Appl. Catal. B, 2009, 86, 159-165.

[46] T. J. Frankcombe, S. C. Smith, J. Phys. Chem. A, 2007, 111, 3686-3690.

\section{低温等离子体组合光催化氧化降解气相甲苯的协同效应：臭氧的作用 \\ 叶昊灵 ${ }^{\mathrm{a}, \mathrm{b}}$, 刘逸秋 ${ }^{\mathrm{a}, \mathrm{b}}$, 陈 思, 王海强, ${ }^{\mathrm{a}, \mathrm{b}}$, 刘 振 ${ }^{\mathrm{c}}$, 吴忠标 ${ }^{\mathrm{a}, \mathrm{b}}$ \\ a浙江大学环境与资源学院污染环境修复与生态健康教育部重点实验室, 浙江杭州 310058 \\ b 浙江省工业锅炉炉窑烟气污染控制工程技术研究中心, 浙江杭州 310027 \\ c浙江大学生物与工程学院生物质化工教育部重点实验室, 浙江杭州 310007}

摘要: 挥发性有机物(VOCs)是导致大气污染的重要成因, 它不仅会直接威胁到人体健康和生态环境, 而且是PM2.5, 臭氧和 光化学烟雾的重要前驱体. 近年来, 低温等离子体(NTP)技术与光催化氧化(PCO)技术等被视作降解VOCs的有效技术而得 到广泛关注. NTP技术的停留时间短, 能耗低, 对于VOCs的降解具有较高的效率, 但是其矿化率较低, 而且会产生臭氧等副 产物. PCO技术能够通过羟基自由基将VOCs完全氧化为 $\mathrm{CO}_{2}$ 和 $\mathrm{H}_{2} \mathrm{O}$, 但是受限于低量子效率, 电子空穴对的快速复合以及 光催化剂的失活. 因此, 将NTP与PCO相结合是提升VOCs的去除率和矿化率, 降低副产物产量的有效策略.

本文以甲苯为VOCs的典型物, $\mathrm{TiO}_{2}$ 为光催化剂, 采用 $\mathrm{NTP}$ 与 $\mathrm{PCO}$ 的组合工艺降解气相甲苯. 为了探索 $\mathrm{NTP}$ 与 $\mathrm{PCO}$ 之间 的协同效应, 我们对单一工艺 $\left(\mathrm{O}_{3}, \mathrm{UV}, \mathrm{NTP}, \mathrm{PCO}\right)$ 与组合工艺 $\left(\mathrm{O}_{3}+\mathrm{TiO}_{2}, \mathrm{O}_{3}+\mathrm{UV}, \mathrm{NTP}+\mathrm{UV}, \mathrm{O}_{3}+\mathrm{PCO}, \mathrm{NTP}+\mathrm{PCO}\right)$ 在甲 苯去除率、 $\mathrm{CO}$ 与 $\mathrm{CO}_{2}$ 选择性、臭氧利用率以及副产物的产生等方面的性能进行了深入考察. 结果表明, NTP与PCO组合工 艺的甲苯去除率为 $80.2 \%$, 远高于单一工艺中NTP的 $18.8 \%$ 和PCO的 $13.4 \%$, 同时也明显高于其他组合工艺. 此外, NTP与 PCO组合工艺的 $\mathrm{CO}_{2}$ 选择性, 矿化率和臭氧利用率也是所有工艺中最优的. 傅里叶透射红外光谱和气相色谱-质谱联用结 果表明, 气相中副产物的产量显著减少; X射线光电子能谱和程序升温脱附-质谱联用的结果表明, 吸附于催化剂表面的碳 基中间产物的含量也显著下降. 结果证明了NTP与PCO两者存在着协同效应, 且只有在臭氧, 紫外光源和光催化剂三者均 存在的情况下才能表现出上述的优异性能. 综上, NTP与PCO组合工艺中所展现的协同效应主要归功于NTP中产生的臭氧 在PCO中获得有效利用. 在这个过程中, 臭氧最重要的作用是充当了电子接收剂和牺牲剂, 因而能够产生更多的羟基自由 基并降低电子-空穴对的复合, 从而提升甲苯去除率、 $\mathrm{CO}_{2}$ 选择性、矿化率和臭氧利用率, 并且降低副产物的含量.

关键词: 低温等离子体; 光催化氧化; 协同效应; 臭氧; 甲苯

收稿日期: 2018-08-29. 接受日期: 2018-10-08. 出版日期: 2019-05-05.

*通讯联系人. 电话/传真: (0571)87953088; 电子信箱: haiqiangwang@zju.edu.cn

基金来源：国家重点研究发展计划(2016YFC0204700); 国家自然科学基金(NSFC-51578488); 浙江省“151”人才计划(2013); 浙江 省重点科技创新团队计划(2013TD07); 长江学者奖励计划(教育部, 2009).

本文的电子版全文由Elsevier出版社在ScienceDirect上出版(http://www.sciencedirect.com/science/journal/18722067). 